\title{
Engaging excellence? Effects of faculty quality on university engagement with industry
}

Article

Accepted Version

Perkmann, M., King, Z. and Pavelin, S. (2011) Engaging excellence? Effects of faculty quality on university engagement with industry. Research Policy, 40 (4). pp. 539-552. ISSN 0048-7333 doi: https://doi.org/10.1016/j.respol.2011.01.007 Available at https://centaur.reading.ac.uk/17064/

It is advisable to refer to the publisher's version if you intend to cite from the work. See Guidance on citing.

To link to this article DOI: http://dx.doi.org/10.1016/j.respol.2011.01.007

Publisher: Elsevier

Publisher statement: NOTICE: this is the author's version of a work that was accepted for publication in Research Policy. Changes resulting from the publishing process, such as peer review, editing, corrections, structural formatting, and other quality control mechanisms may not be reflected in this document. Changes may have been made to this work since it was submitted for publication. A definitive version was subsequently published in Research Policy, [VOL40, ISSUE4, (2011)] DOI10.1016/j.respol.2011.01.007

All outputs in CentAUR are protected by Intellectual Property Rights law, including copyright law. Copyright and IPR is retained by the creators or other copyright holders. Terms and conditions for use of this material are defined in the End User Agreement. 


\section{www.reading.ac.uk/centaur}

\section{CentAUR}

Central Archive at the University of Reading

Reading's research outputs online 
Accepted to appear in Research Policy (2011)

\section{Engaging excellence? Effects of faculty quality on university engagement with industry}

Markus Perkmann $^{\mathrm{a}}$ - Zella King ${ }^{\mathrm{b}}$ - Stephen Pavelin ${ }^{\mathrm{b}}$

${ }^{a}$ Imperial College Business School

South Kensington Campus

London SW7 2AZ (UK)

m.perkmann@imperial.ac.uk

Phone +44 (0)20759 41955

${ }^{\mathrm{b}}$ Henley Business School

University of Reading

P O Box 218

Reading RG6 6AA (UK)

z.m.e.king@reading.ac.uk

s.pavelin@reading.ac.uk 


\title{
Engaging excellence? Effects of faculty quality on university engagement with industry
}

\begin{abstract}
We investigate how universities' research quality shapes their engagement with industry. Previous research has predominantly found a positive relationship between academics' research quality and their commercialization activities. Here we use industry involvement measures that are broader than commercialization and indicate actual collaboration, i.e. collaborative research, contract research and consulting. We hypothesize that the relationship between faculty quality and industry engagement differs across disciplines, depending on complementarities between industrial and academic work, and resource requirements. Using a dataset covering all UK universities, we find that in technology-oriented disciplines, departmental faculty quality is positively related to industry involvement. In the medical and biological sciences we find a positive effect of departmental faculty quality but establish that this does not apply to star scientists. In the social sciences, we find some support for a negative relationship between faculty quality and particularly the more applied forms of industry involvement. The implication for science policy makers and university managers is that differential approaches to promoting university-industry relationships are required.
\end{abstract}

Keywords: University-industry relations; faculty quality; collaborative research; contract research; academic consulting; technology transfer; academic entrepreneurship; commercialization. 


\section{Introduction}

Recent policy has encouraged universities to play an active role in the commercialization of academic knowledge (Siegel et al., 2007; Bercovitz and Feldman, 2006), which has raised questions about the compatibility of the 'disinterested’ pursuit of science (Merton, 1973), and engagement with industry. Important to this enquiry is how faculty quality relates to industry involvement. Are the universities with the most successful researchers also the ones who work most with industry? Or are the more 'applied' universities more successful at establishing relationships with industry despite their academic standing being lower? These questions are of great relevance for policy-makers who attempt to balance the quality of scientific production with the diffusion of university-generated technologies within the wider economy.

The evidence on these issues is mixed. Attitudinal studies suggest that academics at highly rated research universities tend to be wary of excessive commercial involvement for fear it will undermine their academic productivity and independence (Lee, 1996; Glaser and Bero, 2005). Industry involvement may require specific skills and organizational capabilities that are different from those required to excel in the academic arena (Bercovitz and Feldman, 2008). At the same time, a number of studies suggest that faculty quality is positively related to engagement in patenting and academic entrepreneurship (Geuna and Nesta, 2006; Siegel et al., 2007). In other words, faculty who patent more and act more entrepreneurially are also more prolific academic contributors.

Patenting and academic entrepreneurship, however, are imperfect measures of the knowledge transfer and co-creation occurring during university-industry interactions. Relational forms of involvement, such as collaborative research, contract research, and consulting, are more widespread and seen as more relevant by firms (D'Este and Patel, 2007; Cohen et al., 2002). The insights from patenting and academic entrepreneurship, therefore, cannot easily be generalized. Actual relational involvement with industry may demand more faculty time and dedication than patenting, which may be a by-product of the research. Furthermore, collaboration differs from academic entrepreneurship in that it tends to be informed by researchrelated rationales, rather than an explicit desire to appropriate the financial returns on academic knowledge (D'Este and Perkmann, 2010). This means collaboration may be 
more strongly driven by complementarities, achieved by working with industrial partners and pursuing academic research, rather than a single-minded focus on commercial success (Owen-Smith, 2003).

In this paper, we explore how the quality of university faculty is related to their industry engagement via collaborative research, contract research and academic consulting. We contend that university-industry relationships are the outcome of a voluntary matching process (Becker, 1973) between academic and industry partners, shaped by three forces. First, academics' decisions to work with industry are informed by considerations of complementarity with academic research. Second, resource considerations play a role as academics can use the funding gained from industry contracts to supplement grants from public sources. Third, firms are interested in working with high-quality academic researchers because, in addition to seeking project-specific inputs, they are attracted by more generic benefits such as accessing students, 'windows' on emerging technologies, and enhancing their knowledge bases. Relational involvement between universities and industry can be seen, therefore, as a matching process in which partnerships involve academics interested in research complementarity and resources, and firms seeking skilled and competent partners. Our argument is that this matching process plays out differently across academic disciplines. Using a UK dataset, we investigate university engagement in collaborative research, contract research and consulting. We use official quality assessment data derived from the UK Research Assessment Exercise (RAE) to measure the quality of university faculty in various fields. This approach is novel in that we use income data for different types of collaboration across all academic disciplines whereas previous studies have used frequency counts of individual engagement in different types of interactions and/or have been limited to specific disciplines (Louis et al., 1989; D'Este and Patel, 2007).

The paper is organized as follows. First, we review the research on the impact of faculty quality on various types of university technology transfer. We then develop hypotheses on how faculty quality informs industry involvement, taking account of three factors: complementarity between academic and industry work; mobilisation of resources by academics; and partner selection by industry. This leads to specific hypotheses for different disciplinary groups. We exploit data from a UK government survey (HEBCI - Higher Education Business and Community Interaction) of the 164 
universities in England, Wales, Scotland and Northern Ireland. We report our results and discuss our findings in relation to the literature, and derive implications for practice.

\section{Previous research: Faculty quality and engagement in technology transfer}

Extant research has explored how faculty quality relates to engagement in technology transfer using two main measures and various levels of analysis from the university to the department to the individual. One frequently used measure is faculty patenting. Both university-level and individual-level analyses show a predominantly positive relationship between faculty quality and involvement in patenting (Coupé, 2003; Geuna and Nesta, 2006; Stephan, 2007; Carayol, 2007; Van Looy et al., 2006; Breschi et al., 2007). Another popular measure is academic entrepreneurship, where again, the evidence seems to indicate a positive relationship between faculty quality and involvement in commercialization activities (Di Gregorio and Shane, 2003; O'Shea et al., 2005). The findings are similar from individual level studies of 'star scientists' (Zucker and Darby, 1996; Lowe and Gonzalez-Brambila, 2007). The literature, therefore, indicates that faculty quality is largely positively related to technology transfer along the two measures referred to above. Academics who generate high numbers of publications in peer-reviewed journals also excel at patenting and academic entrepreneurship.

However, compared to alternative modes of interaction (Table 1), patenting and academic entrepreneurship are only moderately important means through which industry appropriates university-generated knowledge (Arundel and Geuna, 2004; Perkmann and Walsh, 2007; Faulkner and Senker, 1994; D'Este and Patel, 2007). Roessner (1993), drawing on survey evidence relating to different interaction channels, finds that US research and development (R\&D) executives place the highest value on contract research, followed by co-operative research, with licensing judged as less relevant. According to the Carnegie Mellon Survey on industrial R\&D, US $R \& D$ executives regard consulting, contract research and joint research as more relevant channels than licensing (Cohen et al., 2002). Similar results pointing to the relatively low importance of intellectual property (IP) transfer were found by a number of other studies (Levin et al., 1987; Klevorick et al., 1995; Mansfield, 1991; 
Pavitt, 1991; Agrawal and Henderson, 2002; Schartinger et al., 2002; D'Este and Patel, 2007).

\section{INSERT TABLE 1 ABOUT HERE}

In this paper we focus on these relational forms of engagement. For brevity, we use the term 'industry engagement' to refer to collaborative research, contract research and consulting. Collaborative (or joint) research refers to formal collaborative arrangements aimed at cooperation on R\&D projects (Hall et al., 2001). In many cases, the content of this research can be considered 'pre-competitive', and these projects are often subsidized by public funding. Contract research, on the other hand, refers to research that is directly commercially relevant to firms and, therefore, is usually ineligible for public support. Contract research is explicitly commissioned by firms and the work is usually more applied than in collaborative research arrangements (Van Looy et al., 2004). Finally, consulting refers to research or advisory services provided by individual academic researchers to their industry clients (Perkmann and Walsh, 2008). Consultancy projects are typically commissioned directly by the industry partner and the income derived from them often accrues to individuals although it can be channelled through university research accounts to support research. Studies of academic consulting are hampered by the fact that many consulting activities go unreported (Thursby et al., 2009; Abramovsky et al., 2004). However, a number of both quantitative and qualitative studies suggest consulting is a widespread practice among academic researchers, with most authors finding a positive relationship between faculty quality and consulting engagement (Boyer and Lewis, 1984; Louis et al., 1989; Agrawal and Henderson, 2002).

Industry engagement brings together academics and industry to work jointly on projects, often to complete rather than initiate industry R\&D projects (Cohen et al., 2002). The figures for the UK illustrate the economic value that firms attribute to these interactions (Table 2) and suggest that universities' income from contract research exceeds the income from intellectual property rights (IPR) by a multiple of 15. The ratio is similar for collaborative research, although the predominant share of this income is derived from government grants. 
How is faculty quality related to industry engagement? Published evidence is scant. A study of US life scientists revealed that individuals involved in consulting generate more publications than their non-consulting colleagues (Louis et al., 1989).

Gulbrandsen and Smeby (2005) established that Norwegian professors who receive large amounts of industry funding publish more than their colleagues. Also, the quality of the university has been found to increase industry's utilisation of academic research (Tornquist and Kallsen, 1994).

However, a study by Blumenthal et al. (1996) suggests that while academics who receive large amounts of industry funding also publish more, their publishing output decreases when the ratio of funding from industry relative to public sources exceeds two-thirds. Goldfarb (2008), in a study on the US, found that the rate of academics' publishing declined if they maintained a relationship with a user sponsor, such as NASA (National Aeronautics and Space Administration). A UK study indicates that engineering faculty in departments with lower research rankings are more likely to engage in multiple relationships with industry (D'Este and Patel, 2007). According to data from the US Research Value Mapping Program survey, the higher the average academic quality of an institution, the lower the propensity of individual scientists to interact with the private sector (Ponomariov, 2008).

Finally, Mansfield's (1995) and Mansfield and Lee’s (1996) studies suggest that academics' industry involvement is correlated with research quality and department size. However, discipline-specific analysis shows that research quality is only significant and positive for the electronics and petroleum sectors, with results for the information processing, drugs and chemicals sectors being inconclusive. In addition, of the academic research findings classed by industry respondents as valuable, approximately $40 \%$ originated in universities with 'adequate-to-good' and 'marginal', rather than 'good-to-distinguished' faculties (Mansfield and Lee, 1996). Overall, according to the National Academy of Science rankings, approximately 62\% of industry support for R\&D at the 200 US universities with the largest R\&D expenditures went to universities rated as 'adequate to good', not to the elite 
universities (Mansfield and Lee, 1996). These findings suggest that 'second tier' departments play a significant role in industry’s search for partners.

\section{Hypothesis development}

\subsection{Conceptualising industry engagement}

The above review indicates firstly, that much previous work on the propensity of universities to engage in technology transfer has focused on IP transfer and academic entrepreneurship and secondly, that analyses of collaborative research, contract research and consulting are relatively scarce and yield ambiguous results. In addition, distinctions have not been made between different types of involvement and the relationship with research quality. In this paper, we address these unresolved issues. Our objective is to shed more light on how relational involvement is related to faculty quality. We put particular emphasis on the task environment prevailing in different disciplines, hypothesising that the ambiguous results in the literature might be informed by discipline-specific differences. We postulate that the different ways in which academic research is pursued across disciplines determines the benefits academics derive from collaborating with industry. If different disciplines represent different task environments, patterns of industry collaboration will vary accordingly. To address this issue, we consider the drivers that inform the decisions of academics and industry to collaborate. Theoretically, university-industry relationships are examples of inter-organizational relationships, which can be motivated by a variety of rationales, such as efficiency, reciprocity or stability (Oliver, 1990). Collaboration between academia and industry is voluntary and, hence, collaboration will depend on anticipated benefits (Carayol, 2003). At the same time, collaboration involves competition in the sense that partners sort themselves into partnerships depending on their bargaining positions, which, in turn, depend on their characteristics (Mindruta, 2008). In this respect, university-industry collaboration is analogous to other matching processes, including the formation of business relationships, inter-firm contracting, or even marriage and employment (Mortensen, 1988; Becker, 1973). Each party enters the relationship willingly and the counter-parties must agree if a match is to be achieved (Stuart and Sorenson, 2007).

In our specific case, three drivers are particularly relevant. On the one hand, the decisions of academic researchers to work with industry are informed by two 
rationales: the benefits from the complementarities between their academic work and industry engagement, and the acquisition of additional resources for research. On the other hand, industry partners’ reasons for involvement are based on accessing academic expertise to benefit their $R \& D$ and/or improvement activities. In what follows, we discuss these driving forces in more detail and develop hypotheses about how they relate to the task environments of different academic disciplines.

For academic researchers, the decision to work with firms is likely to be informed significantly by whether this will complement their research (D'Este and Perkmann, 2010). The institutional academic work environment provides powerful incentives for individuals to perform according to the established norms for career progression and assignment of status (Merton, 1973). Furthermore, the higher the standing of a researcher in the academic community, the more their decision will be influenced by the impact that working with industry will have on their academic productivity. More accomplished researchers work in higher-rated departments that place higher value on academic output (Allison and Long, 1990; Crane, 1965). They also belong to peer networks where there is more pressure to perform according to academic metrics (Bercovitz and Feldman, 2008). Such researchers, therefore, will choose to work with industry if the research is complementary to their academic work. Complementarity refers to the relation between pairs of inputs in the sense of relationships between groups of activities (Milgrom and Roberts, 1990). Rather than solely focusing on value creation in the commercial domain, by engaging in intensive collaboration with industry, academics seek to create both industrial and academic value. Working with industry will complement academic research if it provides opportunities for learning via novel insights, ideas and techniques that eventually result in published scientific research. It might be difficult to find complementarity if the outputs from working with industry are not sufficiently novel to be accepted for publication in academic journals. Equally, collaboration might generate time and resources pressures, thereby reducing the ability to concentrate on academically relevant outputs (Calderini et al., 2007). In other words, particularly academics with high standing will more likely engage with industry if it increases their research output.

A second important consideration for academic researchers is that industry partners represent a source of research funding (Louis et al., 1989; Geisler, 1995). In Western Europe (EU15), the share of business-funded R\&D performed in higher education and 
government laboratories was $6.6 \%$ in 2002-2003. ${ }^{1}$ In the US, industry's overall share of support for academic R\&D was approximately $5 \%$ in $2003 .{ }^{2}$ Even though the share of industry funding in overall university research monies appears relatively low, this share is significantly skewed towards certain disciplines. For instance, in the UK, 52\% of industry funding accrues to seven out of a total of 69 disciplines assessed in the 2001 RAE. $^{3}$

Grants and contracts from industry have a significant effect on the propensity of academic researchers to work with industry (Bozeman and Gaughan, 2007). There is evidence that public funding and industry funding are complementary in the sense that researchers who receive considerable grants from both industry and public sources have a higher propensity for involvement with industry (Bozeman and Gaughan, 2007). Similarly, academics’ engagement in ‘informal’ technology transfer, i.e. transfer of commercial technology, publications co-authored with industry scientists, and consulting, is positively correlated with the volume of their research grants (Link et al., 2007). In many countries, public science funding bodies encourage academic researchers to seek matching funding from commercial organizations (Behrens and Gray, 2001; D'Este and Patel, 2007). Overall, the evidence indicates that many academic researchers seek to attract industry funding to increase the overall resources available for research.

The third factor informing the matching process between universities and firms is firms’ motives. Firms work with universities to solicit assistance with specific R\&D projects (Cohen et al., 2002), but at the same time they also seek more generic benefits such as accessing students, gaining insights on emerging technologies and enhancing their knowledge base (Feller, 2005; Caloghirou et al., 2001). The funds that firms spend on working with universities constitutes a conservative indicator of the value that they attach to this kind of knowledge sourcing because their contributions are often matched by public funds. The value may be derived from creating new knowledge in collaborative research projects and from exploiting existing expertise

\footnotetext{
${ }^{1}$ Source: OECD, MSTI database, May 2005.

${ }^{2}$ National Science Foundation, online resource http://www.nsf.gov/statistics/seind06/c5/c5h.htm\#c5hl1, accessed 16/11/08.

${ }^{3}$ In order of ranking, these disciplines are: hospital-based clinical Subjects; mechanical, aeronautical and manufacturing engineering; chemistry; general engineering; biological sciences; business and management studies; and electrical and electronic engineering. We are grateful to Surya Mahdi for providing this information (data source: 2001 RAE).
} 
during consulting assignments. In any case, these benefits are more likely to accrue through collaboration with high-quality partners. Thus, firms can be expected to seek the most skilled and highly reputed collaborators possible. In addition, for firms, the choice is often influenced by considerations of reputation: industry scientists' coauthorship of academic papers with academic collaborators will signal the intellectual leadership of their companies (Hicks, 1995). This in turn increases the ability to recruit talented graduate students and researchers from top universities. Overall, then, we can expect that, given the choice, firms will prefer to work with high-quality academic researchers.

In developing our hypotheses, we will pay attention to a particular feature of the science system, relating to the strongly skewed distribution of outputs and rewards among scientists (Zuckerman, 1970; Merton, 1968). A relatively small number of 'star scientists' account for a disproportionate amount of publications and citations (Zucker and Darby, 1996). Merton (1968), in his characterization of the 'Matthew effect', described how the high status of star scientists provides them with a disproportionate advantage when acquiring resources, which in turn enhance their scientific productivity. Star scientists have also been found to outperform their colleagues in terms of external engagement and commercialization (Zucker and Darby, 1996). Below, we will take into account the special status of star scientists by considering their drivers to engage with industry compared to the mainstream population of scientists.

\subsection{Hypotheses relating to differences across disciplines}

Here, we consider the roles of the three factors discussed in the matching process leading to university-industry collaboration. We suggest that the relationship between high-quality academic work and industry engagement depends on the disciplinespecific task environment, and develop this argument with reference to discipline groups with different characteristics.

First we discuss the technology-oriented disciplines. Within the 'sciences of the artificial' (Simon, 1969), such as engineering, the object of research is often constituted by evolving technological artefacts. Engineering research is aimed ultimately at problem solving for practical ends, and involves gathering knowledge about the functioning or non-functioning of technological processes and artefacts, as documented, for instance, the early aviation industry (Vincenti, 1990). Among the 
various methods of knowledge gathering relevant to engineering projects, academic engineers specialize in more theoretical methods rather than direct trials (Vincenti, 1990). In many cases, academic engineering research remains closely linked to industry technology developments, which constitute the main focus for the creation of new technology (Rosenberg and Nelson, 1994). Academic engineers work with industry, therefore, not just to access research materials, but also to gather information about where to direct their research (Balconi et al., 2004). In turn, this research facilitates and inspires technological progress, hence generating potential benefits for industry (Klevorick et al., 1995). For academic researchers interested in the design, development and use of technological artefacts, therefore, working with industry is likely to be highly complementary with their academic research performance. This may explain why, in technology-oriented disciplines specifically, high degrees of university-industry interaction are associated with high research performance (Balconi and Laboranti, 2006; Mansfield, 1995). Even for star researchers in technologyoriented disciplines, there is considerable academic value in engaging with industry. In addition to providing complementarities with academic research, working with industry will in many cases enhance scientists' resource position as they are able to attract industry funding for contract research and consulting. We therefore postulate: Hypothesis 1a: In technology-oriented academic disciplines, faculty quality is positively related to industry engagement.

Hypothesis 1b: In technology-oriented academic disciplines, having the status of star scientists is positively related to industry engagement.

The relationship between faculty quality and industry engagement in the basic sciences differs from that in the technology-oriented disciplines. Basic science continues to be dominated by usage considerations in the sense that research problems and subjects are inspired by goals informed by industry or society as a whole (Stokes, 1997). However, there is less need to engage interactively with technology producers. Once the broad goals have been set, research in the university laboratory can proceed without constant reference to user considerations. For instance, Pasteur carried out fundamental research into the spoilage of milk and wine, identifying the action of microorganisms as responsible cause (Stokes, 1997). In this type of research, once the practical problem is identified, the research on the fundamental process can proceed without constant interaction with users. 
In this context, industry engagement might lack complementarity with academic research. Specifically, consulting and contract research are aimed at resolving problems or providing guidance for ongoing firm $\mathrm{R} \& \mathrm{D}$, as opposed to pursing novelty (Gibbons, 2000). Hence, these activities usually leverage ‘old science’ (Rosenberg, 1994; Allen, 1977; Gibbons and Johnston, 1974). For academics working in basic science disciplines, providing such 'research services' may not be complementary to novelty-driven academic research and, as a result, they may view consulting as having lower academic value (Boyer and Lewis, 1984). In a UK survey, academics identified two main barriers to engaging in consulting: it was 'not interesting', and it had a 'limiting impact on their career' (Howells et al., 1998). Hence, many academics perceive a trade-off between applied industrial work and their academic research. While basic science might not require high levels of interactivity with developers of industrial technology to generate high-quality academic outcomes, it is nonetheless resource-intensive and many academics may choose to complement their public science funding with industry funds (Blumenthal et al., 1996; Bozeman and Gaughan, 2007). However, industry funding is likely to have some conditions attached to it, raising questions about the influence sponsors might wish to exert on the direction or even outcomes of research, and potential conflicts of interest (Krimsky, 2003). While in the sciences of the artificial these prospective drawbacks are compensated for by the benefits from interactive learning, in the basic sciences these benefits are less clear. Basic researchers with sufficient public funding may be less reliant on industry funding, for example. As faculty quality tends to be positively related to the ability to attract public science funding, less accomplished researchers might be more inclined to tap industry sources of funding than their top-ranked counterparts. This needs to be adjusted for the fact, however, that industry will want to partner with the best-possible academic researchers who are prepared to accept industry funding. Overall this suggests a matching scenario where good researchers engage with industry, but where the most excellent researchers pursue alternative sources of funding:

Hypothesis 2a: In the basic science disciplines, faculty quality is positively related to industry engagement.

Hypothesis 2b: In the basic science disciplines, having the status of star scientists is negatively related with industry engagement. 
There are also a number disciplines that are 'basic', but require smaller amounts of resources; this includes many fields in the social sciences. In these disciplines, we would expect the relationship dynamics to be similar to the basic sciences in the sense that research is usually not closely related to evolving 'technologies'. For instance, in management research - the social science discipline with the highest level of industry funding in the UK - the lack of connection between theory and practice is widely acknowledged (Van De Ven and Johnson, 2006; Gulati, 2007). Social science research considered excellent is usually not concerned with developing practical applications but aims at developing representations of social, economic and organizational realities from a sceptical distance (McKelvey, 1997). While proponents who regard the social science as a 'design science' push for a stronger consideration of application (Romme, 2003), this does not reflect the mainstream view amongst most social scientists. This means that academic researchers do not have a particular need to interact with industrial partners in order to produce high-quality research. In other words, complementarity is likely to be low. Furthermore, as social science is less resource-intensive than science research, there is less pressure for academics to complement public funding with industry funds. Taking both complementarity and resource drivers into account, the relationship between faculty quality and industry involvement is likely to be negative. For star scientists, the relationship is also likely to be negative as they are even less dependent on industry resources and therefore have fewer incentives for engaging in collaboration given that complementarities are absent.

Hypothesis 3a: In the social sciences, faculty quality is negatively related to industry engagement.

Hypothesis 3b: In the social sciences, having the status of star scientists is negatively related to industry engagement.

Below, we examine our hypotheses drawing on data from UK universities.

\section{Data and methods}

\subsection{Data}

Our data on UK universities are drawn from the 2005 Higher Education Business and Community Interaction (HEBCI) survey, and the 2001 Research Assessment Exercise 
(RAE), supplemented by data from the UK's Higher Education Statistical Agency (HESA). Because the provision of these data is mandatory, our dataset includes the complete population of 164 higher education institutions (HEIs) in the UK in 2003/04. In this paper, we refer to all HEIs as universities except when directly reporting responses to a question in the HEBCI survey.

The annual HEBCI survey is issued by the UK's four higher education funding councils - for England, Scotland, Wales and Northern Ireland. The survey captures numeric indicators and financial income arising from 'business and community engagement', and information on a range of themes covering strategy, infrastructure and approaches to the management and commercialization of IP (HEFCE, 2006). 'Business' in this context refers to both public and private sector partners of all sizes and from all sectors, with 'community' taken to mean wider society, including social, civic and cultural organizations and individuals. Our data are drawn largely from the 'business' section of the questionnaire.

The RAE is performed approximately every six years on behalf of the four funding councils to evaluate the quality of research undertaken by UK universities. RAE submissions from each subject area ('unit of assessment') are ranked by a subject specialist peer review panel. These rankings are used to inform the allocation of quality-weighted research funding received by each HEI from their national funding council.

\section{Dependent variables}

We operationalize universities' industry engagement using measures of the income derived from different forms of engagement. These measures are based on the financial section of the HEBCI survey for the academic year 2003/04. Each university reports its income from collaborative research, contract research and consulting. For contract research and consulting only, detailed information about the source of funding is provided, including information on income from local organizations (i.e. those located in the university's region) and from public organizations, small and medium sized enterprises (SMEs) and large firms. We calculated per capita income figures for each of these categories by dividing total income by the total number of academic staff (full time equivalents - FTEs) at each university, derived from RAE data. 
We use several dependent variables, representing different types of income or specific components thereof. Our first three dependent variables are represented by per capita income from collaborative research (COLLABOR), contract research (CONTRACT) and consulting (CONSULT). We also considered per capita income from commercial organizations, for contract research and consulting separately (Firms: CONTRACT, Firms: CONSULT). Further per capita income figures refer to total contract and consulting income from local organizations (LOCAL), SMEs (SME) and large firms (LARGE).

\section{Measures of faculty quality}

For our purposes, we equate faculty quality with their standing in the research community and hence we refer to faculty research quality. We derived measures of research excellence from the 2001 RAE return for each university, pertaining to research activity and output during the five years up to 2000. Since RAE data is collected only approximately every six years, the 2001 data is the most relevant for the period of 2003/04. For each unit of assessment (roughly equating to a discipline) where universities choose to make a RAE submission, they are awarded one of the following scores: $5 *, 5,4,3 a, 3 b, 2,1$. The highest score, $5 *$, equates to international excellence in more than half of the research activity submitted and attainable levels of national excellence in the remainder; the 1 score equates to national excellence in virtually none of the activities submitted. RAE scores have been previously used as an indicator of research quality at both university (McGuinness, 2003; D'Este and Patel, 2007; Ambos et al., 2008) and regional level (Abramovsky et al., 2007). RAE data were collected across 69 units of assessment - roughly corresponding to disciplines which were grouped into five discipline groupings (see Table 10, Annex): physical sciences and engineering, medical and biological sciences, social studies, arts and humanities, and area studies and languages. Our five categories reflect the panels adopted by the UK government for the purposes of carrying out the 2001 RAE; subjects were grouped into disciplines on the basis of having similar approaches to research.

In our analysis, we focus on the three biggest discipline groupings. We regard the physical and engineering sciences as representative of the technology-oriented disciplines as, according to RAE data, most industry income in this category accrues to the engineering subjects. In turn, we conceptualize the medical and biological 
sciences as basic as most industry income benefits the biological sciences and clinical-based subjects - the latter are data collection exercises to allow analysis of physiological and molecular processes. To measure faculty quality, we constructed two measures for each discipline grouping. The first measure which we call 'standard research quality', represents the share of 'good' researchers in each university. We operationalize this as a proportion of research-active staff in each discipline grouping, calculated by dividing the number of research-active staff in each grouping with an RAE score of 4 or above by the total number of academic staff in that grouping. Table 3 shows how faculty quality is distributed across all universities.

\section{INSERT TABLE 3 ABOUT HERE}

This measure controls for the size of each discipline group at each university, mirroring our use of per capita income figures as the dependent variables. We constructed our measure in the following way. As only the number of research active staff in each unit of assessment was reported, we had to estimate the total number of staff (FTE) for each unit of assessment. We were able to do this because the RAE data report the proportion of research active staff for each unit of assessment (within a range), relative to the total number of staff. We used the midpoint of the range to estimate total academic staff numbers for each discipline group. Then, for each of the five discipline groupings, we divided the number of research-active staff (in FTEs) in each unit of assessment that received a RAE score of 4 or above, by the estimated total number of academic staff of the respective discipline grouping. This generated five variables for each university: the proportion of 'good' researchers in the Physical and Engineering Sciences (PHYS), Medical and Biological Sciences (MED), Social Sciences (SOC), Arts and Humanities (ARTS), and Area Studies and Languages (LANG). ${ }^{4}$ In our analysis, we focus on the explanatory power of faculty quality in the three largest discipline groupings (PHYS, MED, SOC) but we retain the measures in the smaller disciplines (ARTS, LANG) to control for the possible impact they may have on determining universities’ income from industry interaction.

\footnotetext{
${ }^{4}$ University of Manchester and London Metropolitan University had been involved in mergers in the period between the $2001 \mathrm{RAE}$ and the 2005 HEBCI survey. The RAE returns for the pre-merger institutions were combined.
} 
The second measure which we call 'star research quality' reflects the presence of star scientists. We constructed a dummy variable reflecting whether a university had at least one department classified as $5^{*}$ in a given discipline grouping. This resulted in the following variables, indicating researchers in 'excellent' departments: PHYS*, MED*, SOC*, ARTS*, and LANG*. These measures moderate the effect of faculty quality by adding a marker for top-rated researchers. Taken together, these two measures allow us to account for any threshold effects by distinguishing between 'good' and 'excellent' researchers. The variables used are summarized in Table 4.

\section{INSERT TABLE 4 ABOUT HERE}

Our quality measures apply to departments and not individuals, and therefore the results of our analysis refer to how the quality of departments of a university relates to its engagement with industry. This may be justified by the fact that within departments there may be a relative homogeneity of individuals in terms of their research quality but our results should nevertheless be read as applying to an organizational level and not an individual level.

\section{Control variables}

We used a number of control variables to account for effects unrelated to research quality.

The total number of staff in the institution (in FTEs), FTEtotal, was included in order to control for size effects. A positive coefficient indicates that the returns per staff member are greater when the institution is larger. This variable is derived from HESA's annual report of staff FTEs.

Since some UK universities are highly specialized (say, covering only the arts or medical sciences) we included a measure of specialization (SPECIALIZE) for each university, using a Herfindahl index. The proportion of total staff (FTE) in each of the five discipline groups is squared, and the squares summed to give a value ranging from 0.2 (an equal spread across all five areas) to 1 (activities within only one of the five areas). 
We capture differences in terms of organizational heritage with a dummy variable (Post1992). 'Post-1992' universities were previously classified as tertiary education teaching institutions ('polytechnics') in England, Wales and Northern Ireland, and Central Institutions in Scotland, and were mostly established during the 1960s' expansion of higher education in the UK. Their original remit was to teach both academic and practical subjects with a focus on engineering and applied science, although they subsequently created departments in other fields. Under the Further and Higher Education Act, 1992 they were nominated universities, but retain many of their original features, in particular a closeness to employers' vocational interests and routine engagement with business. D’Este and Patel (2007) report that science and engineering researchers at post-1992 universities engage in a wider variety of interactions with industry, although these findings apply to collaboration in basic rather than applied physical sciences.

We also include variables to capture the university's infrastructure and rules supporting university-industry collaboration. Survey respondents reported how many of their university staff (FTEs) were employed in a dedicated 'business and community function' to engage with (a) commercial partners and (b) public sector partners. Based on these responses we created the variables STAFFcom (the proportion of staff engaged with commercial partners) and STAFFpub (the proportion of staff engaged with public sector partners).

We identified the existence of strategic plans for industry engagement (HEIplan) from the responses to the question: Does your HEI have a strategic plan for business support? Responses were scored on a scale ranging from 1 (no strategic plan in place; ad hoc approach to business support), through 3 (strategic plan developed and only partially implemented, or restricted to certain departments or central functions only) to 5 (strategic plan developed as a result of an inclusive process across the whole university; accepted across almost all units and recommendations implemented; use of plan to set targets and monitor achievement). Intervening responses related to between 1 and 3 or between 3 and 5 .

With regard to the rules for disclosure, respondents were asked about the requirement within the HEI to report inventions, choosing one of three possible responses: always, usually, or rarely/never. We created a binary variable (Disclose) to indicate either a requirement to always or usually report inventions, or rarely or never to do so. We 
used a measure (Mature) to evaluate the university's experience in supporting consulting links, derived from the age of the department, to manage consultancy links and other external interactions with missing values set to zero. Finally, following Siegel et al. (2003), we included a measure (Regional) reflecting overall R\&D expenditure by business in university’s local region.

\subsection{Method}

In Section 5, we present the results of the regressions for the various dependent variables. Due to a prevalence of zeros in the dependent variables, all models use Tobit estimations (Greene, 1990). Our regressions employ econometric model specifications that incorporate the explanatory variables described above. The number of observations in the regressions was 132, which was due to some missing values (which are discussed further below). Given the potential for correlation between various university characteristics, we test for the presence of multicollinearity using Variance Inflation Factors (VIFs). For all model specifications, the VIFs are sufficiently low (below 4) to infer that multicollinearity poses no significant problem for our study. For each model, we report sigma and the value of the Likelihood Function, but, unfortunately, there is no accepted goodness-of-fit statistic for Tobit estimation.

\section{Results}

Table 5 presents the descriptive statistics and a correlation matrix for our key variables.

\section{INSERT TABLES 5, 6, 7 and 8 ABOUT HERE}

Table 6 presents average values (per capita income figures) separately for post-1992 universities and Russell Group universities. Post-1992 universities are less researchactive institutions with a focus on teaching (see above), while Russell Group universities include the most research-intensive universities in the UK. The figures show that per capita income is considerably higher in research-intensive universities than in less research-intensive institutions, with the exception of consulting income, which is relatively evenly distributed across all types of universities. 
Below, we present the results of our econometric models taking account of disciplinary differences. First, we consider our results for income from the three types of industry engagement - collaborative research (COLLABOR), contract research (CONTRACT) and consultancy (CONSULT) (Table 7). Regression 1 provides evidence that income from collaborative research is positively associated with standard research quality in the Social Sciences (SOC; $\mathrm{p}=0.001$ ) and star research quality in area studies and languages (LANG; $\mathrm{p}=0.030$ ), but negatively associated with star research quality in the medical and biological sciences. No significant effect is found to be associated with star research quality in either the arts and humanities or the physical and engineering sciences. Income from collaborative research is also positively affected by a requirement to disclose inventions (Disclose; $\mathrm{p}=0.000$ ) and is higher for the universities that are more narrowly focused across disciplines (Specialize; $\mathrm{p}=0.026$ ).

The results are somewhat different for contract research income, CONTRACT. Regression 2 in Table 7 shows a positive effect for standard research quality in the medical and biological sciences (MED; $\mathrm{p}=0.000$ ), but no other discipline is associated with a significant influence. Also, unlike the previously discussed measure, CONTRACT is found to be increasing with university size (Size; $\mathrm{p}=0.044$ ), which implies a significant degree of increasing returns to scale. Furthermore, we find that having a strategic plan for industry engagement has a positive impact on contract research income (Strategy; $\mathrm{p}=0.003$ ), and that regional expenditure on $\mathrm{R} \& \mathrm{D}$ has a (somewhat surprising) negative effect on these income streams.

For income from consultancy (CONSULT) the results differ again. Regression 3 shows a positive effect associated with star research quality researchers in both the physical and engineering sciences (PHYS*; p=0.002) and the social sciences (SOC*; $\mathrm{p}=0.060$ ). We also find consulting income to be positively affected by the employment of staff to engage with commercial partners within a dedicated business and community function (STAFFcom; $\mathrm{p}=0.021$ ), but to be negatively associated with university size, which implies a significant degree of decreasing returns to scale. Income from relationships with local organizations (LOCAL), reported in column 4 of Table 8, is significantly influenced by only the presence and composition of research quality. More specifically, there is a positive effect associated with standard research quality in both the physical and engineering sciences (PHYS; $\mathrm{p}=0.008$ ) and 
the arts and humanities (ARTS; $\mathrm{p}=0.085$ ) but a negative effect associated with research quality in the Social Sciences (SOC; $\mathrm{p}=0.094$ ).

Next we look at those parts of the incomes from contract research and consulting that accrue from relationships with firms only, the results of which are reported in Regressions 5 and 6 in Table 8. For contract research, the results for firms only can be usefully contrasted with those for the more aggregate measure in Regression 2. There are three key differences: while we find a positive effect from standard research quality in the medical and biological sciences (MED; $\mathrm{p}=0.000$ ), we find a negative association with star research quality in the social sciences (SOC; $\mathrm{p}=0.088$ ) for only firm-related contract research; the negative effect of regional $R \& D$ expenditures on the aggregate measure disappears once the focus is on relationships with firms only; and the more specific measure, unlike the case for CONTRACT, is positively affected by the requirement to disclose inventions (Disclose; $\mathrm{p}=0.042$ ).

For consulting, the results for firms can be usefully contrasted with those reported for the corresponding aggregate measure in Regression 3. Again, there are some differences: a positive effect of star research quality in the physical and engineering sciences is found for both (PHYS*; $\mathrm{p}=0.017$ for firm-related income); while star research quality in the Social Sciences has a positive effect on aggregate consulting income, no such effect is found for the more specific measure; for firm-related consulting there is a negative association with star research quality in area studies and languages (LANG*; $\mathrm{p}=0.026$ ); and we find that standard research quality in the medical and biological sciences has a positive effect on firm-related, but not aggregate, consulting income (MED; $\mathrm{p}=0.093$ ) and the decreasing returns to scale result is absent for the more specific measure. In addition, unlike CONSULT, firmrelated consulting income is positively affected by the requirement to disclose inventions (Disclose; $\mathrm{p}=0.074$ ).

Finally, we turn to our measures of income disaggregated by type of firm - SME and LARGE - whose results are reported in Regressions 7 and 8 in Table 8. For SME, similarly to the results for local organizations, we find a positive effect associated with standard research quality in both the physical and engineering sciences (PHYS; $\mathrm{p}=0.042$ ) and the arts and humanities (ARTS; $\mathrm{p}=0.064$ ), but a negative effect associated with standard research quality in the Social Sciences (SOC; $\mathrm{p}=0.062$ ). However, we find the effect on income from SMEs is positive for star research quality 
in the physical and engineering sciences (PHYS*; $\mathrm{p}=0.008$ ), and that relationships with SMEs are significantly less fruitful in the presence of star research quality in the medical and biological sciences (MED*; $\mathrm{p}=0.009$ ), but are improved by the employment of staff to engage with commercial partners (STAFFcom; $\mathrm{p}=0.023$ ). We find that a requirement to disclose inventions promotes income from relationships with both SMEs and large firms (Disclose; $\mathrm{p}=0.097$ and $\mathrm{p}=0.058$, respectively), but with the exception of this effect, the results for large firms are starkly different from those for SMES and local firms. We find evidence that income from relationships with large firms is positively affected by standard research quality in the Medical and biological Sciences (MED; $\mathrm{p}=0.000$ ) and negatively associated with star research quality in Area studies and languages (LANG; $\mathrm{p}=0.038$ ). Furthermore, there is evidence of increasing returns to scale (Size; $\mathrm{p}=0.008$ ), and positive effects associated with both the existence of strategic plans for industry engagement (Strategy; $p=0.025$ ) and a narrower focus across disciplines (Specialize; $\mathrm{p}=0.056$ ).

We lose a number of observations due to a lack of data availability. Out of the 164 universities surveyed by HEBCI, 132 enter our sample. This arises because some institutions' survey responses were incomplete and also because some made no RAE return. Regarding this loss of information, it is worth emphasising that the institutions excluded from the sample are dominated by non-research-active, teaching-only colleges that would be a poor fit for our model of knowledge creation, collaboration and transfer. For such institutions, the phenomena upon which this study focuses reflect at most only peripheral objectives and activities. A few examples of excluded institutions are: the Arts Institute at Bournemouth; the Conservatoire for Dance and Drama; the Courtauld Institute of Art; the Royal Welsh College of Music and Drama; Ravensbourne College of Design and Communication; Trinity Laban; and the Royal Academy of Music.

Table 9 presents a synthesis of the results for various measures of industry involvement, including significant results only for the variables relating to faculty quality. For the physical and engineering sciences (Hypotheses 1a and 1b), we find the proportion of good researchers to be positively related to income from local firms as well as SMEs, and the presence of top-rated researchers to be positively related to income from contract research and consulting as well as income from SMEs and 
consulting with firms. Therefore, Hypothesis 1a is supported by two income measures, and Hypothesis $1 \mathrm{~b}$ by four income measures for excellent researchers.

INSERT TABLE 9 ABOUT HERE

For the medical and biological sciences (Hypotheses 2a and 2b), we find a generally positive relationship between the proportion of good researchers, as indicated by standard research quality, and income from firms, and specifically large firms, and both contract research and consulting with firms. However, we find a negative relationship between the presence of top-rated researchers, as indicated by star research quality, and income from collaborative research and from SMEs. Hypothesis 2a, therefore, is supported by four income measures showing a positive association between income and good researchers, and hypothesis $2 \mathrm{~b}$ is supported by two income measures showing a negative association between income and top-rated researchers. For the social sciences (Hypotheses 3a and 3b), we find a positive relationship between the proportion of good researchers and income from collaborative research. However, income from contract research, local firms and SMEs is negatively related to the proportion of good researchers. Furthermore, income from consulting is positively affected by the presence of top-rated researchers, while income from contract research from firms is negatively affected. Thus, there is conflicting evidence for Hypotheses 3a and 3b. On the one hand, the hypotheses are supported by three income measures showing a negative association between income and good researchers, and two income measures showing a negative association between income and top-rated researchers. On the other hand, however, there is one income measure that shows a positive association with good researchers, and one that shows a positive association with top-rated researchers.

\section{Discussion}

This paper provides novel empirical evidence on an aspect of university-industry relationships where existing studies are ambiguous and incomplete. Overall, we find that the relationship between faculty quality and industry involvement differs according to disciplinary orientation. The insights can be summarized as follows. 
Within the physical and engineering sciences, industry involvement in its various guises is positively related to faculty research quality, measured as the proportion of good researchers, as well as the presence of top-ranked researchers. The higher a department is ranked in terms of research quality, the more likely its members will get involved in some type of collaboration with industry. This finding provides some support for Hypotheses 1a and 1b, which posited that in technology-oriented academic disciplines, faculty quality would be positively related to industry engagement. We know from other sources that industry income within the physical and engineering sciences is concentrated in applied disciplines such as mechanical and manufacturing engineering (Mahdi et al., 2008). Therefore, the positive association we find between successful researchers and industry engagement is likely to be strongly informed by the presence of the technology-oriented sciences, as postulated in our hypotheses.

In the medical and biological sciences, we encounter a different dynamic. While income from firms for contract research and consulting is positively related to the proportion of good researchers in a department, for top-ranked departments, this effect disappears and even becomes negative for some types of income. This means we find some support for Hypothesis 2a that in these disciplines, faculty quality is positively related to industry engagement, particularly when it comes to working with large firms. However, as proposed in Hypothesis $2 b$, the very top tier researchers are less inclined to work with industry. It appears that in these disciplines, compared to the more application-oriented fields in the physical and engineering sciences, the best researchers are less dependent on working with industry to pursue top-level research. These researchers usually receive more public research grants than lower-ranked researchers, and may therefore be less dependent on engaging with outside partners to attract resources.

Where resource requirements play a less important role, such as in the social sciences, we would expect a negative relationship between faculty quality and industry involvement, as postulated in Hypotheses 3a and 3b. Our results for the social sciences are indicative of a such as relationship, although we find a positive association between the proportion of good researchers and involvement in collaborative research. This indicates that good researchers are attracted by the type of relationships with industry that are less applied and where objectives are defined 
collaboratively. By contrast, the involvement of researchers in relationships where objectives are defined more unilaterally by the partners, such as contract research and consulting, decreases with research quality.

A somewhat counter-intuitive finding is that involvement in consulting is positively associated with top-ranked researchers. This may indicate that top-ranked social science researchers prefer to consult for government, or that governments prefer to recruit top-tier researchers for consultancy opportunities. We did not find an equivalent relationship regarding consulting for firms, and a negative association between researchers' quality and involvement in contract research for firms, suggesting that social scientists' engagement with firms is not unequivocally related to their research quality. Taken together, these findings suggest that matching processes between academics and their external collaborators are driven by different considerations across scientific disciplines.

This study contributes to the literature by differentiating the factors shaping matching processes in the establishment of university-industry relationships. This type of collaboration represents a special case of interorganizational relationship (Oliver, 1990). Both parties are free to enter these relationships and their decisions will therefore be based on the benefits they can expect from collaborating. We have argued that match-making is informed by several factors. For academic researchers, two considerations are relevant: the task-based complementarity between industry work and the their research, and mobilisation of funding from industry. Industry's involvement is promoted by a desire to source knowledge from skilled and reputable researchers, resulting in a preference for cooperation with high-quality researchers. Within technology-oriented disciplines, high levels of complementarity between toplevel research and its application, increase the tendency for top-ranked researchers to work with industrial partners, including SMEs. In these disciplines, firms with advanced equipment and materials platforms providing a basis for collaborative development of technological artefacts are able to attract the top-ranked academic researchers. In contexts of lower levels of complementarity, such as in the medical and biological sciences, academic researchers are still motivated to work with industry, but perhaps predominantly to access resources. The higher their standing in terms of research quality, the more easily they will be able to raise income from industry. However, industry partners might have to compromise on research quality, 
since star researchers have recourse to alternative ways of mobilising funds and unlike in the technology-oriented disciplines, do not need collaborative development of technological artefacts with industry to underpin the quality of their scientific research. In turn, when fewer resources are required for research, such as in the social sciences, academic researchers with higher standing appear to be less inclined to work with industry. For top-tier social scientists, time may be more of a constraint on doing academic research than resources, making them very selective about choices of partners and projects.

Our results have implications for the literature on academics' engagement in commercialization (Rothaermel et al., 2007). Existing work finds primarily positive relationships between measures of faculty quality, such as publication counts, and measures of industry engagement, such as academic entrepreneurship and particularly patenting (Baldini, 2008). Patenting data allows for precise analysis, but it represents only an indirect measure of academics' involvement with industry. Data on the income from these relationships, used in this paper, are also imperfect but are a closer measure of actual involvement with industry. In fact, patents are often the outcome of the relationships maintained by academics with industry, for instance, via consulting contracts (Thursby et al., 2007). In addition, it is well established that patenting is highly skewed across academic disciplines (Geuna and Nesta, 2006) while collaborative relationships within industry are more widespread (Schartinger et al., 2002). Finally, patents intrinsically incorporate scientific and technological findings with high degrees of novelty and, therefore, have a high affinity with articles in highly-rated academic journals (Murray and Stern, 2007).

Our results suggest that commercialization behaviour, (patenting and academic entrepreneurship), and collaborative involvement (collaborative research, contract research and consulting) are driven by different dynamics. Only in certain disciplines are high levels of industry collaboration associated with star scientists. It appears that the difference between research based on patenting data and collaborative engagement, respectively, can be interpreted by making a distinction between value appropriation and value creation. Patenting represents a way for academic researchers to appropriate some value from their research, and it appears from previous research that top-level researchers are always the ones who excel at industrial value appropriation. Collaborative engagement, by contrast, can be seen as a value creation 
activity during which benefits are yet to be generated. Academics' engagement with industry, via relationships such as contract research and consulting, often takes the form of providing advice on ongoing R\&D work rather than focusing on novel technological inventions (Cohen et al., 2002; Perkmann and Walsh, 2009). Our results indicate that value creation is not necessarily the exclusive domain of top-ranked researchers.

This emerging picture qualifies some of the claims recently advanced emphasising growing complementarities between universities and industry. For instance, the 'triple helix' theory depicts universities, industry and government as part of a coherent system underpinning innovation and economic progress (Etzkowitz and Leydesdorff, 2000). Better grounded in empirical evidence, Owen-Smith (2003) finds a 'hybrid regime' linking commercial and academic activities via positive feedback loops. According to our findings, these hybrid regimes where the best researchers are always those who also engage most with industry, operate in some fields, but not in others. Therefore, the universality of the 'triple helix' and 'hybrid regimes' views should not be taken for granted.

Our analysis represents a first effort to investigate the impact of faculty quality on university income in collaborative research, contract research and consulting across a broad set of disciplines. However, it has some limitations. First, university-level analysis necessarily yields less fine-grained results than would individual or department-level analysis. Therefore, our results might neglect potentially relevant variables not captured by university-wide measures. For instance, within departments, there might be a division of labour between academics who excel in scientific publishing and those who 'specialize' in working with industry and generate less output in terms of publications. However, this limitation should be judged against the fact that data on income from industry interactions at departmental or individual level are scarce and difficult to collect. Another limitation is that our dependent variables only measure income, not necessarily industry involvement. Any involvement with firms that does not result in actual income for the university is not captured. This might include non-monetary, informal exchanges between academics and industry (Kreiner and Schultz, 1993; King, 2006) or consulting income that is not declared to the university administration. A third limitation is that our data do not allow us to observe whether faculty quality is associated with the ability to engage effectively 
with industry. An alternative interpretation of our findings for the basic and social sciences may be that lower-tier faculty are actually better at understanding the problems of and communicating with firms, making them more attractive partners for industry. Future research, therefore, should focus on substantiating or rejecting our findings.

\section{Conclusion}

We began this paper by asking whether the universities with the most successful researchers are also the ones who work most with industry or whether more 'applied' universities are more successful at establishing relationships with industry despite lower academic standing. This question is highly relevant for policy making that attempts to balance the quality of scientific production with the diffusion of university-generated technologies within the wider economy. Our analysis of UK universities revealed that there is no uniform relationship between industry involvement and faculty quality across disciplines. For the technology-oriented disciplines, the researchers in the best departments are also those with high industry involvement. This alignment is due to the high levels of complementarity between academic research and technology development.

For disciplines such as the medical and biological sciences we find that research quality is also positively related to industry engagement but interestingly this relationship reverses for the very best departments. We attribute this effect to the fact that in these disciplines the complementarities between academic research and industrial requirements are lower and therefore those researchers with the best access to public grants, (i.e. the star scientists), may have to resort to industry funds to a lower degree. For the social sciences, which are less resource-intensive, we find a mostly negative relationship between faculty quality and particularly the more applied forms of industry involvement.

These findings have implications for universities and policy makers keen to promote university engagement with industry. Our results matter because, in terms of overall economic impact, the types of industry engagement analysed in this paper are more pervasive than IP transfer and academic entrepreneurship. In the technology-oriented disciplines, industry involvement is strongly complementary with top-level scientific research (Balconi and Laboranti, 2006; Mansfield, 1995). This means the diffusion of 
university-generated technologies into the economy is progressed through highquality scientific production and commercialization in these disciplines, and for that reason it may be easier for universities to configure structures, resources and incentives to encourage engagement in contract and collaborative research as a means to achieve academic excellence.

Our findings suggest that this complementarity is less apparent in basic and social science disciplines. Here, if top quality researchers are not the most active pursuers of industry engagement, then there might be a tension between providing incentives for such activities, and top-level research, meaning universities must find creative ways for managing these different demands. Strategies and policies to promote academics' interactions with industry, universities and policy-makers must be tuned to take account of these differences between academic disciplines. Currently, policy-makers are considering a division of labour among universities whereby some specialize in advanced research and others in business engagement (Sainsbury of Turville, 2007). According to our findings, such an arrangement might be appropriate for some disciplines, but less so for others.

Acknowledgements: We thank Oliver Alexy, Janet Bercovitz, John Bessant, Johan Bruneel, Pablo d’Este, Maryann Feldman, Martin Kenney, Francesco Lissoni, Andrew Nelson, Bart Nooteboom, Don Siegel, Ammon Salter, Bruce Tether, Finn Valentin, Vareska van de Vrande, Kathryn Walsh, and Arend Zomer for helpful comments. Previous versions presented at the EGOS 2008 conference in Amsterdam, the DRUID 2010 conference in London, and the Academy of Management Annual Meeting 2010 in Montreal. We thank Adrian Day at the Higher Education Funding Council for England (HEFCE) for his help. We benefitted from Maryam Philpott's skilful editorial assistance. Markus Perkmann acknowledges funding from the UK Engineering and Physical Sciences Research Council (EPSRC) (EP/C534239/1) and the UK Economic and Social Research Council (ESRC) via an AIM Management Practices Fellowship (RES-331-27-0063). Zella King acknowledges support from ESRC via response-mode funding (RES-000-22-0867). 


\section{References}

Abramovsky, L., Harrison, R., Simpson, H., House, S., Bristol, B. S., 2007. University research and the location of business R\&D. Economic Journal 117(519), C114-C141.

Abramovsky, L., Kremp, E., López, A., Schmidt, T., Simpson, H., 2004. Understanding co-operative R\&D activity: evidence from four European countries. Institute of Fiscal Studies Working Paper 05/23, London.

Agrawal, A., Henderson, R. M., 2002. Putting patents in context: Exploring knowledge transfer from MIT. Management Science 48(1), 44-60.

Allen, T. J., 1977. Managing the flow of technology: Technology transfer and the dissemination of technological information within the R \& D organization. MIT Press, Cambridge.

Allison, P. D., Long, J. S., 1990. Departmental effects on scientific productivity. American Sociological Review 55(4), 469-478.

Ambos, T. C., Mäkelä, K., Birkinshaw, J., D’Este, P., 2008. When does university research get commercialized? Creating ambidexterity in research institutions. Journal of Management Studies 45(8), 1424-1447.

Arundel, A., Geuna, A., 2004. Proximity and the use of public science by innovative European firms. Economics of Innovation and New Technology 13(6), 559580.

Balconi, M., Breschi, S., Lissoni, F., 2004. Networks of inventors and the role of academia: An exploration of Italian patent data. Research Policy 33(1), 127145.

Balconi, M., Laboranti, A., 2006. University-industry interactions in applied research: The case of microelectronics. Research Policy 35(10), 1616-1630.

Baldini, N., 2008. Negative effects of university patenting: Myths and grounded evidence. Scientometrics 75(2), 289-311.

Becker, G. S., 1973. A theory of marriage: Part I. Journal of Political Economy 81(4), 813-846.

Behrens, T. R., Gray, D. O., 2001. Unintended consequences of cooperative research: Impact of industry sponsorship on climate for academic freedom and other graduate student outcome. Research Policy 30(2), 179-199.

Bercovitz, J., Feldman, M., 2006. Entrepreneurial universities and technology transfer: A conceptual framework for understanding knowledge-based economic development. Journal of Technology Transfer 31(1), 175-188.

Bercovitz, J., Feldman, M., 2008. Academic entrepreneurs: Organizational change at the individual level. Organization Science 19(1), 69-89. 
Blumenthal, D., Campbell, E. G., Causino, N., Louis, K. S., 1996. Participation of life-science faculty in research relationships with industry. New England Journal of Medicine 335(23), 1734-1739.

Boyer, C. M., Lewis, D. R., 1984. Faculty consulting: Responsibility or promiscuity? Journal of Higher Education 55(5), 637-659.

Bozeman, B., Gaughan, M., 2007. Impacts of grants and contracts on academic researchers' interactions with industry. Research Policy 36(5), 694-707.

Breschi, S., Lissoni, F., Montobbio, F., 2007. The scientific productivity of academic inventors: new evidence from Italian data. Economics of Innovation and New Technology 16(2), 101-118.

Calderini, M., Franzoni, C., Vezzulli, A., 2007. If star scientists do not patent: The effect of productivity, basicness and impact on the decision to patent in the academic world. Research Policy 36(3), 303-319.

Caloghirou, Y., Tsakanikas, A., Vonortas, N. S., 2001. University-industry cooperation in the context of the European framework programmes. Journal of Technology Transfer 26(1-2), 153-161.

Carayol, N., 2003. Objectives, agreements and matching in science-industry collaborations: Reassembling the pieces of the puzzle. Research Policy 32(6), 887-908.

Carayol, N., 2007. Academic incentives, research organization and patenting at a large French university. Economics of Innovation and New Technology 16(2), 119-138.

Cohen, W. M., Nelson, R. R., Walsh, J. P., 2002. Links and impacts: The influence of public research on industrial R\&D. Management Science 48(1), 1-23.

Coupé, T., 2003. Science is golden: Academic R\&D and university patents. Journal of Technology Transfer 28(1), 31-46.

Crane, D., 1965. Scientists at major and minor universities: a study of productivity and recognition. American Sociological Review 30(5), 699-714.

D'Este, P., Patel, P., 2007. University-industry linkages in the UK: What are the factors determining the variety of interactions with industry? Research Policy 36(9), 1295-1313.

D'Este, P., Perkmann, M., 2010. Why do academics engage with industry? The entrepreneurial university and individual motivations. Journal of Technology Transfer (in press),

Di Gregorio, D., Shane, S., 2003. Why do some universities generate more start-ups than others? Research Policy 32(2), 209-227. 
Etzkowitz, H., Leydesdorff, L., 2000. The dynamics of innovation: From National Systems and "Mode 2" to a Triple Helix of university-industry-government relations. Research Policy 29(2), 109-123.

Faulkner, W., Senker, J., 1994. Making sense of diversity: Public-private sector research linkage in three technologies. Research Policy 23(6), 673-695.

Feller, I., 2005. A historical perspective on government-university partnerships to enhance entrepreneurship and economic development, in: S. Shane (Eds.), Economic development through entrepreneurship: Government, university and business linkages. Edward Elgar, Cheltenham, pp. 6-28.

Geisler, E., 1995. Industry-university technology cooperation: A theory of interorganizational relationships. Technology Analysis \& Strategic Management 7(2), 217-229.

Geuna, A., Nesta, L. J. J., 2006. University patenting and its effects on academic research: The emerging European evidence. Research Policy 35(6), 790-807.

Gibbons, M., 2000. Changing patterns of university - industry relations. Minerva 38(3), 352-361.

Gibbons, M., Johnston, R., 1974. The roles of science in technological innovation. Research Policy 3(3), 220-242.

Glaser, B., Bero, L., 2005. Attitudes of academic and clinical researchers toward financial ties in research: A systematic review. Science and Engineering Ethics 11(4), 553-573.

Goldfarb, B., 2008. The effect of government contracting on academic research: Does the source of funding affect scientific output. Research Policy 37(1), 41-58.

Gulati, R., 2007. Tent poles, tribalism, and boundary spanning: The rigor-relevance debate in management research. Academy of Management Journal 50(4), 775782.

Gulbrandsen, M., Smeby, J. C., 2005. Industry funding and university professors' research performance. Research Policy 34(6), 932-950.

Hall, B. H., Link, A. N., Scott, J. T., 2001. Barriers inhibiting industry from partnering with universities: evidence from the Advanced Technology Program. Journal of Technology Transfer 26(1), 87-98.

HEFCE, 2006. Higher education-business and community interaction survey 2003-04. Higher Education Funding Council for England, London.

Hicks, D., 1995. Published papers, tacit competencies and corporate management of the public/private character of knowledge. Industrial \& Corporate Change 4(2), 401-424.

Howells, J., Nedeva, M., Georghiou, L., 1998. Industry-academic links in the UK. PREST, University of Manchester, Manchester 
King, Z., 2006. Knowledge production and university-business interaction in the life sciences. Online resource: www.reading.ac.uk/nmsruntime/saveasdialog.asp?lID=12089\&sID=50515 (accessed 27/02/2008).

Klevorick, A. K., Levin, R. C., Nelson, R. R., Winter, S. G., 1995. On the sources and significance of interindustry differences in technological opportunities. Research Policy 24(2), 185-205.

Kreiner, K., Schultz, M., 1993. Informal collaboration in R\&D: the formation of networks across organizations. Organization Studies 14(2), 189-209.

Krimsky, S., 2003. Science in the private interest: has the lure of profits corrupted the virtue of biomedical research? Rowman \& Littlefield, Lanham.

Lee, Y. S., 1996. 'Technology transfer' and the research university: A search for the boundaries of university-industry collaboration. Research Policy 25(6), 843863.

Levin, R. C., Klevorick, A. K., Nelson, R. R., Winter, S. G., 1987. Appropriating the returns from industrial research and development. Brookings Papers on Economic Activity 1987(3), 783-820.

Link, A. N., Siegel, D. S., Bozeman, B., 2007. An empirical analysis of the propensity of academics to engage in informal university technology transfer. Industrial and Corporate Change 16(4), 641-655.

Louis, K. S., Blumenthal, D., Gluck, M., Stoto, M. A., 1989. Entrepreneurs in academe: an exploration of behaviors among life scientists. Administrative Science Quarterly 34(1), 110-131.

Lowe, R., Gonzalez-Brambila, C., 2007. Faculty entrepreneurs and research productivity. Journal of Technology Transfer 32(3), 173-194.

Mahdi, S., D'Este, P., Neely, A. D., 2008. Citation counts: Are they good predictors of RAE scores? A bibliometric analysis of RAE 2001. Working Paper, Advanced Institute of Management Research (AIM), London.

Mansfield, E., 1991. Academic research and industrial innovation. Research Policy 20(1), 1-12.

Mansfield, E., 1995. Academic research underlying industrial innovations: Sources, characteristics, and financing. Review of Economics and Statistics 77(1), 5565.

Mansfield, E., Lee, J. Y., 1996. The modern university: Contributor to industrial innovation and recipient of industrial R\&D support. Research Policy 25(7), 1047-1058.

McGuinness, S., 2003. University quality and labour market outcomes. Applied Economics 35(18), 1943-1955. 
McKelvey, B., 1997. Quasi-natural organization science. Organization Science 8(4), 352-380.

Merton, R. K., 1968. The Matthew effect in science. The reward and communication systems of science are considered. Science 159(3810), 56-63.

Merton, R. K., 1973. The sociology of science. Theoretical and empirical investigations. Chicago, London, University of Chicago Press.

Milgrom, P., Roberts, J., 1990. Rationalizability, learning, and equilibrium in games with strategic complementarities. Econometrica 58(6), 1255-1277.

Mindruta, D., 2008. Value creation in university-firm research collaborations: A matching approach. Academy of Management Annual Meeting, Anaheim

Mortensen, D. T., 1988. Wages, separations, and job tenure: On-the-job specific training or matching? Journal of Labor Economics 6(4), 445-471.

Murray, F., Stern, S., 2007. Do formal intellectual property rights hinder the free flow of scientific knowledge? An empirical test of the anti-commons hypothesis. Journal of Economic Behavior and Organization 63(4), 648-687.

O'Shea, R. P., Allen, T. J., Chevalier, A., Roche, F., 2005. Entrepreneurial orientation, technology transfer and spinoff performance of US universities. Research Policy 34(7), 994-1009.

Oliver, C., 1990. Determinants of interorganizational relationships: integration and future directions. Academy of Management Review 15(2), 241-265.

Owen-Smith, J., 2003. From separate systems to a hybrid order: accumulative advantage across public and private science at Research One universities. Research Policy 32(6), 1081-1104.

Pavitt, K., 1991. What makes basic research economically useful? Research Policy 20(2), 109-119.

Perkmann, M., Walsh, K., 2007. University-industry relationships and open innovation: towards a research agenda. International Journal of Management Reviews 9(4), 259-280.

Perkmann, M., Walsh, K., 2008. Engaging the scholar: three forms of academic consulting and their impact on universities and industry. Research Policy 37(10), 1884-1891.

Perkmann, M., Walsh, K., 2009. The two faces of collaboration: impacts of university-industry relations on public research. Industrial and Corporate Change 18(6), 1033-1065.

Ponomariov, B. L., 2008. Effects of university characteristics on scientists' interactions with the private sector: An exploratory assessment. Journal of Technology Transfer 33(5), 485-503. 
Roessner, J. D., 1993. What companies want from the Federal labs. Issues in Science and Technology 10(1), 37-42.

Romme, A. G. L., 2003. Making a difference: Organization as design. Organization Studies 14(5), 558-574.

Rosenberg, N., 1994. Exploring the black box: technology, economics, and history. Cambridge University Press, Cambridge.

Rosenberg, N., Nelson, R. R., 1994. American universities and technical advance in industry. Research Policy 23(3), 323-348.

Rothaermel, F. T., Agung, S., Jiang, L., 2007. University entrepreneurship: a taxonomy of the literature. Industrial and Corporate Change 16(4), 691-791.

Sainsbury of Turville, L., 2007. The race to the top: A review of Government's science and technology policies HM Treasury

Schartinger, D., Rammer, C., Fischer, M. M., Fröhlich, J., 2002. Knowledge interactions between universities and industry in Austria: Sectoral patterns and determinants. Research Policy 31(3), 303-328.

Siegel, D. S., Waldman, D. A., Atwater, L. E., Link, A. N., 2003. Commercial knowledge transfers from universities to firms: improving the effectiveness of university-industry collaboration. Journal of High Technology Management Research 14, 111-133.

Siegel, D. S., Wright, M., Lockett, A., 2007. The rise of entrepreneurial activity at universities: Organizational and societal implications. Industrial and Corporate Change 16(4), 489-504.

Simon, H. A., 1969. The sciences of the artificial. MIT Press, Cambridge.

Stephan, P. E., 2007. Who's patenting in the university? Evidence from the survey of doctorate recipients. Economics of Innovation and New Technology 16(2), 7199.

Stokes, D. E., 1997. Pasteur's quadrant: Basic science and technological innovation. Brookings Institution Press, Washington, D.C.

Stuart, T. E., Sorenson, O., 2007. Strategic networks and entrepreneurial ventures. Strategic Entrepreneurship Journal 1(3-4), 211-228.

Thursby, J., Fuller, A., Thursby, M., 2007. US faculty patenting: inside and outside the university. NBER Working Paper 13256,

Thursby, J., Fuller, A., Thursby, M., 2009. US faculty patenting: inside and outside the university. Research Policy 38(1), 14-25.

Tornquist, K. M., Kallsen, L. A., 1994. Out of the ivory tower: Characteristics of institutions meeting the research needs of industry. Journal of Higher Education 65(5), 523-539. 
Van De Ven, A. H., Johnson, P. E., 2006. Knowledge for theory and practice. Academy of Management Review 31(4), 802-821.

Van Looy, B., Callaert, J., Debackere, K., 2006. Publication and patent behavior of academic researchers: Conflicting, reinforcing or merely co-existing? Research Policy 35(4), 596-608.

Van Looy, B., Ranga, M., Callaert, J., Debackere, K., Zimmermann, E., 2004. Combining entrepreneurial and scientific performance in academia: towards a compounded and reciprocal Matthew-effect? Research Policy 33(3), 425-441.

Vincenti, W. G., 1990. What engineers know and how they know it: Analytical studies from aeronautical history. Johns Hopkins University Press, Baltimore.

Zucker, Lynne G., Darby, Michael R., 1996. Star scientists and institutional transformation: Patterns of invention and innovation in the formation of the biotechnology industry. Proceedings of the National Academy of Sciences 93(23), 12709-12716.

Zuckerman, H., 1970. Stratification in American Science. Sociological Inquiry 40(2), 235-257.

\section{Annex}

INSERT TABLE 11 ABOUT HERE 
Table 1: Types of university-industry relations

\begin{tabular}{ll}
\hline Licensing & $\begin{array}{l}\text { Contractual assignment of university-generated } \\
\text { intellectual property (such as patents) to external } \\
\text { organizations }\end{array}$ \\
\hline Academic entrepreneurship & $\begin{array}{l}\text { Development and commercial exploitation of } \\
\text { technologies pursued by academic inventors through } \\
\text { a company they (partly) own }\end{array}$ \\
\hline Collaborative research & $\begin{array}{l}\text { Research jointly pursued by university and industrial } \\
\text { partners - commonly with public funding }\end{array}$ \\
\hline Contract research & $\begin{array}{l}\text { Application-oriented research and development } \\
\text { activities carried out by university - commissioned } \\
\text { and funded by industry }\end{array}$ \\
\hline Consulting & $\begin{array}{l}\text { Application-oriented research and development } \\
\text { activities or advice provided individually by } \\
\text { academics - commissioned and funded by industry }\end{array}$ \\
\hline
\end{tabular}

Compiled from several sources (Bercovitz and Feldman, 2006; Mansfield, 1995;

Louis et al., 1989).

Table 2: UK universities’ income from industry involvement

\begin{tabular}{lr}
\hline Type of interaction with industry & Income \\
\hline Collaborative research & 541 \\
\hline Contract research & 580 \\
\hline Consulting & 211 \\
\hline Facilities and equipment & 80 \\
\hline Intellectual property (licensing and spin-outs) & 38 \\
\hline
\end{tabular}

In Million GBP. Source: Higher Education Funding Council (2006).

Table 3: Distribution of faculty quality across universities

\begin{tabular}{lccc}
\hline & $\begin{array}{l}\text { Physical and } \\
\text { Engineering } \\
\text { Sciences }\end{array}$ & $\begin{array}{l}\text { Medical and } \\
\text { biological } \\
\text { sciences }\end{array}$ & $\begin{array}{l}\text { Social } \\
\text { Sciences }\end{array}$ \\
\hline $1^{\text {st }}$ Quartile & 0.00 & 0.00 & 0.00 \\
\hline 2nd Quartile & 0.00 & 0.00 & 0.04 \\
\hline 3rd Quartile & 0.42 & 0.42 & 0.40 \\
\hline $4^{\text {th }}$ Quartile & 0.89 & 0.88 & 0.85 \\
\hline Overall average & 0.33 & 0.33 & 0.32 \\
\hline
\end{tabular}

Average proportion of faculty in departments with RAE ratings of 4 or higher, relative to total research active staff, for each quartile of universities. 
Table 4: Independent variables

\begin{tabular}{ll}
\hline PHYS & Proportion of good researchers in the Physical and Engineering Sciences \\
\hline PHYS* & Presence of star researchers in the Physical and Engineering Sciences \\
\hline MED & Proportion of good researchers in the Medical and Biological Sciences \\
\hline MED* & Presence of star researchers in the Medical and Biological Sciences \\
\hline SOC & Proportion of good researchers in the Social Sciences \\
\hline SOC* & Presence of star researchers in the Social Sciences \\
\hline ARTS & Proportion of good researchers in the Arts and Humanities \\
\hline ARTS* & Presence of star researchers in the Arts and Humanities \\
\hline LANG & Proportion of good researchers in Languages and Area Studies \\
\hline LANG* & Presence of star researchers in Languages and Area Studies \\
\hline Size & Number of staff (full-time equivalents) \\
\hline Strategy & Presence of university strategy for business engagement \\
\hline STAFFpub & University staff engaged in making links with public sector \\
\hline STAFFcom & University staff engaged in making links with private sector \\
\hline Disclose & Presence of policy requiring disclosure of inventions \\
\hline Regional & Regional Business Expenditure on R\&D \\
\hline Specialize & Degree of disciplinary specialization by university \\
\hline Post1992 & Indicates status as Post-1992 university (previous 'polytechnic') \\
\hline Mature & Age of university office for managing consulting links \\
\hline
\end{tabular}




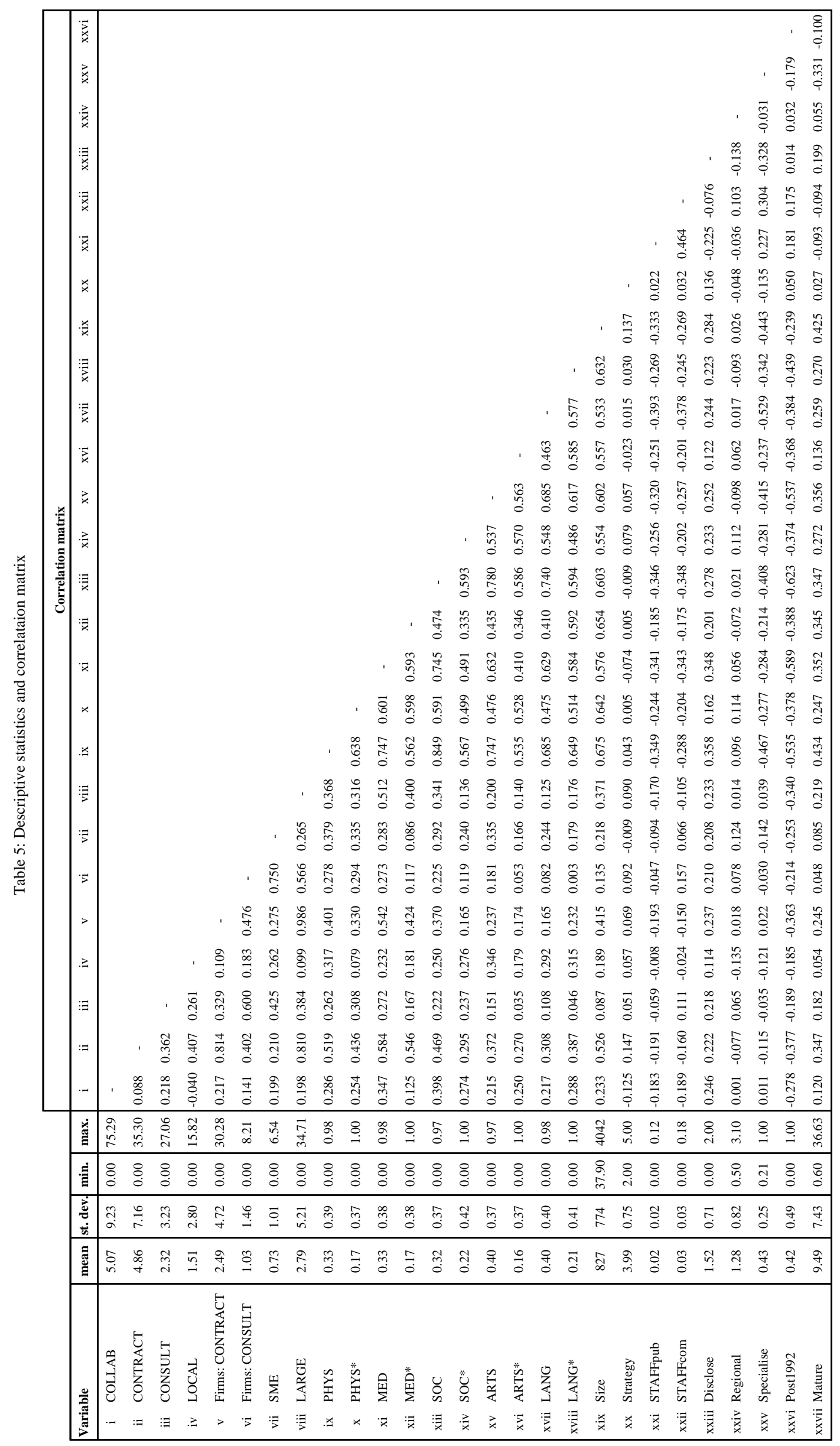


Table 6: Average income per member of faculty for different types of universities

\begin{tabular}{lccc}
\hline & $\begin{array}{l}\text { Collaborative } \\
\text { Research }\end{array}$ & $\begin{array}{l}\text { Contract } \\
\text { research }\end{array}$ & Consulting \\
\hline $\begin{array}{l}\text { Post 1992 } \\
\text { universities }\end{array}$ & 2,049 & 1,680 & 1,598 \\
\hline $\begin{array}{l}\text { Russell Group } \\
\text { universities }\end{array}$ & 8,748 & 14,385 & 2,435 \\
\hline $\begin{array}{l}\text { Other } \\
\text { universities }\end{array}$ & 6,827 & 5,234 & 2,934 \\
\hline $\begin{array}{l}\text { Average (all } \\
\text { universities) }\end{array}$ & 5,069 & 4,862 & 2,317 \\
\hline
\end{tabular}

Figures represent GBP amounts. Faculty members measured as full-time equivalent. Source: Higher Education Funding Council (2006)

Table 7: Tobit regression results for three income measures

\begin{tabular}{|l|c|c|c|}
\cline { 2 - 4 } \multicolumn{1}{c|}{} & \multicolumn{3}{c|}{ Regression } \\
\cline { 2 - 4 } \multicolumn{1}{c|}{} & $\mathbf{3}$ & $\mathbf{2}$ & $\mathbf{3}$ \\
\cline { 2 - 4 } \multicolumn{1}{c|}{ Variable } & COLLAB & CONTRACT & CONSULT \\
\hline Constant & -8.613 & $-9.948 * *$ & -1.585 \\
PHYS & -6.360 & 4.059 & 1.164 \\
PHYS* & 1.870 & -0.949 & $3.150 * * *$ \\
MED & 2.701 & $9.164 * * *$ & 1.298 \\
MED* & $-5.854 *$ & 3.179 & 0.306 \\
SOC & $16.444 * * *$ & 2.703 & 0.989 \\
SOC* & 0.333 & -1.267 & $1.585 *$ \\
ARTS & -2.882 & -2.748 & 0.120 \\
ARTS* & -1.266 & 0.347 & -1.239 \\
LANG & -2.394 & -1.836 & -1.007 \\
LANG* & $5.885 * *$ & -2.192 & -1.133 \\
Size & 0.001 & $0.002 * *$ & $-0.001 * *$ \\
Strategy & -0.948 & $2.195 * * *$ & 0.401 \\
STAFFpub & -21.340 & -32.147 & -15.018 \\
STAFFcom & -16.736 & 17.549 & $22.414 * *$ \\
Disclose & $4.961 * * *$ & -0.166 & 0.651 \\
Regional & 0.681 & $-1.597 * *$ & -0.089 \\
Specialise & $10.647 * *$ & 2.946 & 0.551 \\
Post1992 & 1.539 & 0.935 & 0.300 \\
Mature & 0.096 & 0.096 & 0.050 \\
\hline
\end{tabular}

1: $\mathrm{N}=132$; Sigma $=8.088(\mathrm{p}=0.000)$; Likelihood function $=-416.6$

2: $\mathrm{N}=132 ;$ Sigma $=5.515(\mathrm{p}=0.000)$; Likelihood function $=-359.9$

3: $\mathrm{N}=132$; Sigma $=2.807(\mathrm{p}=0.000)$; Likelihood function $=-313.8$

$*$, ** and ${ }^{* * *}$ denote significance at the $90 \%, 95 \%$ and $99 \%$ level of confidence, respectively. 
Table 8: Tobit regression results for income from relationships with firms, disaggregated by type of firm and type of relationship

\begin{tabular}{|l|c|c|c|c|c|}
\cline { 2 - 6 } \multicolumn{1}{c|}{} & \multicolumn{5}{c|}{ Regression } \\
\cline { 2 - 6 } & $\mathbf{4}$ & $\mathbf{5}$ & $\mathbf{6}$ & $\mathbf{7}$ & $\mathbf{8}$ \\
\cline { 2 - 6 } Variable & & \multicolumn{3}{|c|}{ Dependent variable } \\
\hline Constant & LOCAL & CONTRACT & CONSULT & SME & LARGE \\
\cline { 2 - 6 } PHYS & -4.293 & $-8.859 * * *$ & -1.010 & 0.316 & $-10.203 * * *$ \\
PHYS & $5.430 * * *$ & 2.538 & 0.926 & $1.044 * *$ & 1.773 \\
MED & -1.805 & -1.248 & $1.150 * *$ & $0.888 * * *$ & -1.006 \\
MED* & -0.021 & $7.423 * * *$ & $0.989 *$ & 0.174 & $8.878 * * *$ \\
SOC & 0.635 & 0.576 & -0.497 & $-0.877 * * *$ & 1.063 \\
SOC* & $-4.062 *$ & 1.666 & 0.316 & $-1.102 *$ & 2.961 \\
ARTS & 1.493 & $-1.963 *$ & -0.233 & -0.040 & -2.036 \\
ARTS* & $2.718 *$ & -2.742 & 0.247 & $0.767 *$ & -2.642 \\
LANG & -0.773 & -0.332 & -0.330 & -0.460 & -0.026 \\
LANG* & 2.296 & -2.220 & -0.483 & 0.113 & -2.518 \\
Size & 1.020 & -2.054 & $-1.020 * *$ & -0.141 & $-3.035 * *$ \\
Strategy & 0.000 & $0.003 * *$ & 0.000 & 0.000 & $0.002 * * *$ \\
STAFFpub & 0.145 & $1.051 * *$ & 0.215 & -0.086 & $1.228 * *$ \\
STAFFcom & 26.481 & -24.524 & -5.261 & -1.035 & -18.031 \\
Disclose & 7.319 & 6.529 & $14.554 * * *$ & $7.245 * *$ & 14.012 \\
Regional & 0.118 & $1.304 * *$ & $0.369 *$ & $0.238 *$ & $1.304 *$ \\
Specialise & -0.204 & -0.195 & -0.017 & 0.094 & -0.307 \\
Post1992 & 1.831 & $4.138 *$ & -0.147 & -0.369 & $4.697 *$ \\
Mature & 1.230 & -0.299 & -0.141 & -0.383 & 0.468 \\
\hline 4 N & -0.026 & 0.034 & -0.018 & -0.013 & 0.030 \\
\hline
\end{tabular}

4: $\mathrm{N}=132 ;$ Sigma $=3.267$ ( $\mathrm{p}=0.000)$; Likelihood function $=-247.9$

5: $N=132 ;$ Sigma $=3.780(p=0.000)$; Likelihood function $=-305.0$

6: $N=132$; Sigma $=1.317$ ( $p=0.000)$; Likelihood function $=-209.5$

7: $N=132$; Sigma $=0.907$ ( $p=0.000)$; Likelihood function $=-165.7$

8: $\mathrm{N}=132$; Sigma $=4.147$ ( $\mathrm{p}=0.000$ ); Likelihood function $=-326.6$

$*$, ** and $* * *$ denote significance at the $90 \%, 95 \%$ and $99 \%$ level of confidence, respectively. 
Table 9: Relationship between faculty quality and modes of industry involvement

\begin{tabular}{|c|c|c|c|c|c|c|c|}
\hline Inco & from & Jrganiz & tions & Income & from fir & is only & \\
\hline $\begin{array}{l}\text { Coll. } \\
\text { Res. }\end{array}$ & $\begin{array}{l}\text { Contr } \\
\text { Res. }\end{array}$ & $\begin{array}{l}\text { Con- } \\
\text { sulting }\end{array}$ & $\begin{array}{l}\text { Local } \\
\text { contract } \\
\text { \& consul. }\end{array}$ & $\begin{array}{l}\text { SMEs } \\
\text { (contr. } \\
\text { \& cons) }\end{array}$ & $\begin{array}{l}\text { Large } \\
\text { firms } \\
\text { (contr. } \\
\text { \& cons) }\end{array}$ & $\begin{array}{l}\text { Contr. } \\
\text { Res. }\end{array}$ & $\begin{array}{l}\text { Con- } \\
\text { sulting }\end{array}$ \\
\hline
\end{tabular}

\begin{tabular}{|c|c|c|c|c|c|c|c|c|c|}
\hline PHYS & good & & & & + & + & & & \\
\hline PHYS* & Top & & + & + & & + & & & + \\
\hline MED & good & & & & & & + & + & + \\
\hline MED* & Top & - & & & & - & & & \\
\hline SOC & good & + & - & & - & - & & & \\
\hline SOC* & Top & & & + & & & & - & \\
\hline
\end{tabular}

For various types of industry involvement, the table indicates the direction of significant coefficients (at 90\% level of confidence) of dependent variables indicating 'good' researchers and 'top' researchers for different discipline groups.

Table 10: Categorization of disciplines into groups

\begin{tabular}{ll}
\hline Arts & Classics, Ancient History, Byzantine and Modern Greek Studies \\
(ARTS) & Archaeology \\
& History \\
& History of Art, Architecture and Design \\
& Library and Information Management \\
& Philosophy \\
& Theology, Divinity and Religious Studies \\
& Art and Design \\
& Communication, Cultural and Media Studies \\
& Drama, Dance and Performing Arts \\
& Music \\
& Built Environment \\
& Town and Country Planning \\
& Geography \\
& Law \\
Social & Anthropology \\
Economics and Econometrics & Politics and International Studies \\
& Social Policy and Administration \\
& Social Work \\
& Sociology \\
Business and Management Studies \\
Accounting and Finance \\
Education \\
Sports-related Subjects \\
\end{tabular}




\begin{tabular}{ll}
\hline Medical \& & Medical Laboratory Sciences \\
biological & Community-based Medical Subjects \\
(MED) & Hospital-based Medical Subjects \\
& Medical Dentistry \\
& Pre-Medical Studies \\
& Anatomy \\
& Physiology \\
& Pharmacology \\
& Pharmacy \\
& Nursing \\
& Other Studies and Professions Allied to Medicine \\
& Psychology \\
& Biological Sciences \\
& Agriculture \\
& Food Science and Technology \\
Veterinary Science
\end{tabular}


Table 4 (cont'd): Categorization of disciplines into groups

\begin{tabular}{ll}
\hline Physical \& & Chemistry \\
engineering & Physics \\
(PHYS) & Earth Sciences \\
& Environmental Sciences \\
& Pure Mathematics \\
& Applied Mathematics \\
& Statistics and Operational Research \\
& Computer Science \\
& General Engineering \\
& Chemical Engineering \\
& Civil Engineering \\
& Electrical and Electronic Engineering \\
& Mechanical, Aeronautical and Manufacturing Engineering \\
& Mineral and Mining Engineering \\
& Metallurgy and Materials \\
\hline Area \& & American Studies \\
Languages & Middle Eastern and African Studies \\
(LANG) & Asian Studies \\
& European Studies \\
& Celtic Studies \\
& English Language and Literature \\
& French \\
& German, Dutch and Scandinavian Languages \\
& Italian \\
& Russian, Slavonic and East European Languages \\
& Iberian and Latin American Languages \\
& Linguistics \\
\hline
\end{tabular}

As corresponding to the 'units of assessment' used in the UK Research Assessment Exercise 2001. 